\title{
T-Box Transcription Factor TBX3
}

National Cancer Institute

\section{Source}

National Cancer Institute. T-Box Transcription Factor TBX3. NCI Thesaurus. Code C101640.

T-box transcription factor TBX3 (743 aa, $79 \mathrm{kDa})$ is encoded by the human TBX3 gene.

This protein is involved in both the negative regulation of transcription and embryogenesis. 